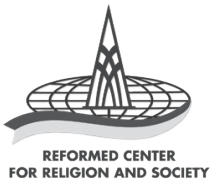

Societas Dei: Jurnal Agama dan Masyarakat Vol. 08, No. 1 (April 2021): 57-84

http://societasdei.rcrs.org/index.php/SD/issue/archive

p-ISSN: 2407-0556; e-ISSN: 2599-3267

DOI: $10.33550 /$ sd.v8i1.197

Received: 13 November 2020

Revised: 29 January 2021

Accepted: 22 March 2021

\title{
MAKNA KISAH PANGGILAN PARA MURID YESUS BAGI METODE PENDIDIKAN AGAMA KRISTEN
}

\section{THE MEANING OF JESUS DISCIPLES' VOCATION FOR THE CHRISTIAN EDUCATION METHOD}

\section{Yusuf Siswantara}

Fakultas Filsafat, Universitas Katolik Parahyangan, Bandung

yusuf.siswantara@unpar.ac.id 


\title{
Abstract:
}

Jesus is a teacher who sets an example of His teaching to the disciples. The story of the early disciples' vocation provides evidence that Jesus is expertise in personal development. This fact is a moral criticism issue that is not in line with religious values and a challenge to Christian religious education which means the Church work in the educational issue. Through a library research approach, this study aims to explore the pedagogical meaning and methods of Christian religious education in vocational stories (Matthew 4: 18-22, Markus. 1: 16-20, Luke 5: 1-14). The focus is on the pedagogical meaning, methodology and implementation of the teachings of Jesus in the vocational story. The result is an imaginative analogy, a term that affirms the educational meaning of Christian religious and educational methodology where the experience (in the light of) faith is accompanied by acts that are much more effective in Christian religious education.

Keywords: Pedagogy; Educational Methods; Christian Religious Education; Disciples of Jesus.

\begin{abstract}
Abstrak:
Yesus merupakan sosok guru yang memberikan keteladanan dalam pengajaran-Nya kepada para murid. Kisah panggilan murid-murid perdana memberikan bukti kepiawaian Yesus dalam pengembangan pribadi dan iman para murid, sekaligus menyiratkan makna pedagogis di dalamnya. Kenyataan ini merupakan kritik pada kenyataan persoalan moral yang kurang selaras dengan nilai agama, dan menjadi tantangan pada pendidikan agama Kristen sebagai karya gereja dalam bidang pendidikan. Melalui pendekatan library research, penelitian ini bertujuan untuk mengeksplorasi makna pedagogis dan metode pendidikan agama Kristen dalam kisah panggilan (Matius 4: 18-22, Markus. 1: 16-20, Lukas 5: 1-14). Fokusnya adalah makna pedagogis, metodologi dan implementasi dari pengajaran Yesus dalam kisah panggilan. Hasilnya adalah analogi imajinatif, suatu terminologi yang menegaskan bahwa makna pendidikan agama Kristen dan metodologi pendidikan, di mana pengalaman (dalam terang) iman yang disertai tindakan iman jauh lebih berdaya guna dalam pendidikan agama Kristen.
\end{abstract}

Kata-kata kunci: Pedagogi; Metode Pendidikan; Pendidikan Agama Kristen; Murid Yesus. 


\section{Pendahuluan}

Banyak masalah sosial terjadi, dan hal itu berkaitan dengan moral dan karakter: pelanggaran hak asasi manusia, kekerasan, narkotika, kematangan seksual remaja dan ekspresinya, dan lain sebagainya. Ujaran kebencian mudah terlontar, bukan hanya dari kaum awam tetapi bahkan dari mereka yang menyatakan diri agamawan. Di sisi lain, media sosial dalam dunia digital memperkuat berkembangnya masalah tersebut. Masalah moral dan karakter menjadi tren masalah sosial yang layak untuk dicari solusi pedagogisnya.

Kurikulum pendidikan sebenarnya selalu disusun, direncanakan secara sadar dan sistematik, dan dilaksanakan sedemikian rupa sehingga potensi kemanusiaan peserta didik dapat berkembang dalam berbagai domain dan aspek, khususnya karakter dan nilai. Sistem pendidikan nasional pun telah merancang pendidikan dengan paradigma filosofi pendidikannya. Dalam jenjang pendidikan (dasar, menengah, dan tinggi), muatan pendidikan disusun seimbang dan tidak hanya terpusat pada pengetahuan, tetapi meliputi emosi dan perilaku. Pendidikan tidak hanya membantu peserta didik untuk cerdas dan pandai, tetapi juga mengembangkan sikap dan pribadi yang baik dan berakhlak mulia. Namun, ironisnya, kondisi sosial menyatakan bahwa output pendidikan moral dan karakter bertentangan dengan tujuan dan rancangan pendidikan.

Dalam kondisi problematis di atas, pendidikan agama Kristen tidak dapat cuci tangan. Sebaliknya, pendidikan agama Kristen dihadapkan pada kaca benggala ${ }^{1}$ untuk merenungkan dan merefleksikan diri. Apakah pendidikan agama Kristen berhenti pada sekadar pengetahuan tentang agama yang secara faktual juga dilakukan dalam berbagai kegiatan keagamaan? Lalu, bagaimana pendidikan agama Kristen mampu mengelola diri sebagai sarana pengembangan dan pembentukan karakter? ${ }^{2}$ Melihat hal-hal ini, penulis tergerak untuk mengeksplorasi metode pendidikan karakter yang dilakukan oleh Yesus sebagai Guru Agung yang tersaji di kitab suci dan validitas dampaknya dalam pengajaran kekristenan itu sendiri.

Secara pedagogis, pendidikan karakter menjadi keniscayaan dalam pendidikan. ${ }^{3}$ Dalam kerangka ini, terdapat dua pandangan: internal dan

\footnotetext{
Kaca benggala, secara harafiah, berarti cermin tebal (besar). Dalam khazanah budaya Jawa, kaca benggala dapat berarti 'mawas diri', evaluasi diri, refleksi atas hidup untuk mendapatkan makna atas keberadaannya.

2 Binsen Samuel Sidjabat, "Kerangka Kurikulum Pendidikan Agama Kristen Berbasis Karakter di Perguruan Tinggi Character-Based Christian Religious Education Curriculum Framework in Higher Education," Jurnal Jaffray 17, no. 1 (2019): 76-77, https://doi.org/10.25278/jj.v17i1.314.

Alfian Dwi Primantoro, "Pendidikan Nilai Moral Ditinjau dari Perspektif Global," JPK: Jurnal Pancasila dan Kewarganegaraan 1, no. 1 (2016): 1-8.
} 
eksternal. Yang pertama adalah dimensi internal. Kadarminto bisa mewakili dimensi internal dengan menggali pendidikan karakter dalam kaitannya dengan restorasi atau transformasi. Di dalam restorasi, pendidikan karakter dibawa pada wilayah dosa, kuasa Roh Kudus, dan teosentris. Alur gagasannya adalah sebagai berikut. Allah menciptakan manusia sebagai citra-Nya. Namun, dosa manusia telah merusak citra Allah dalam dirinya. Karena cinta-Nya yang begitu besar, Allah sendiri menawarkan pemulihan dan penebusan dosa sebagai langkah awal restorasi. Karya penebusan memungkinkan dan menjadi dasar tindakan manusia untuk membina diri selaras dengan kodrat awalnya, yaitu suci. Inilah proses restorasi citra Allah dalam diri manusia. ${ }^{4}$ Dengan demikian, pemikiran dasar yang dibangun adalah bahwa pendidikan karakter dimulai dari hati (iman) dengan mengembalikan kesejatian manusia kepada Allah Sang Pencipta. Sejalan dengan hal ini, Setiawan yang mengangkat gagasan "lahir baru" sebagai fondasi dan titik awal pembentukan karakter. ${ }^{5}$ Lahir baru menjadi pintu gerbang pemulihan hakikat manusia sebagai citra Allah dan prakondisi bagi pendidikan karakter yang baik dan berdaya guna. Sisi batin manusia menjadi titik tolak bagi pendidikan diri. Dalam hatinya, ia menerima Yesus sebagai jalan menuju Allah. ${ }^{6}$

Kedua, dimensi eksternal. Sidjabat mengusulkan pendidikan karakter dalam sistem atau kurikulum pendidikan Kristen (khususnya pendidikan tinggi, tanpa menutup jenjang pendidikan dasar dan menengah). Dengan mendasarkan diri pada gagasan Wight, Sidjabat mengusulkan lima jalur pendidikan karakter dalam pendidikan agama Kristen: scriptura (analisis tematik teks Kitab Suci), life story (kisah hidup tokoh), example (keteladanan sikap tokoh), community (berbagi pengalaman), dan practices (praktik, melakukan sesuatu). Kelima jalur tersebut dapat dilakukan secara terbuka dan pendidikan karakter dapat dimulai dari jalur mana saja. ${ }^{7}$

Gagasan-gagasan di atas telah menghasilkan pemikiran pedagogis. Demikian pula banyak penelitian lain berupaya menggali pendidikan karakter berbasis kekristenan, seperti implementasi nilai toleransi dalam

\footnotetext{
4 "Mengkaji Revolusi Mental dalam Perspektif Pendidikan Kristen," Polyglot: A Journal of Language, Literature, Culture, and Education 12, no. 1 (2016): 103-18, https://ojs.uph.edu/index.php/PJI/article/ view/388/178.

5 Bagi Setiawan, Kelahiran baru mengacu pada peristiwa pembaptisan sebagai pintu gerbang bagi hidup dan dunia baru dalam Yesus Kristus. Kehidupan baru tersebut ditandai dengan hadirnya Kerajaan Allah dan ditambahkannya identitas baru sebagai Anak Allah.

6 "Kelahiran Baru di Dalam Kristus Sebagai Titik Awal Pendidikan Karakter Unggul," Evangelikal: Jurnal Teologi Injili dan Pembinaan Warga Jemaat 3, no. 2 (2019): 154, https://doi.org/10.46445/ejti.v3i2.135.

Sidjabat, "Kerangka Kurikulum Pendidikan Agama Kristen Berbasis Karakter di Perguruan Tinggi Character-Based Christian Religious Education Curriculum Framework in Higher Education."
} 
pendidikan agama, ${ }^{8}$ penguatan pendidik agama dalam era digital, korelasi dan relasionalitas antara nilai-nilai, guru, dan pelajaran agama, ${ }^{9}$ ataupun penguatan pendidik Kristen. ${ }^{10}$ Namun, Fønnebø, L. (2011) mengingatkan bahwa pendidikan telah berlangsung sepanjang manusia ada tetapi telaah metodologi yang berdasarkan pandangan dunia Kristen sulit ditemukan padahal Yesus diyakini sebagai salah satu guru terbesar di dunia. Fønnebø rupanya ingin mengembalikan dimensi kristologi sebagai basis pendidikan. Baginya, kehidupan Yesus menginspirasi seluruh umat manusia, terkhusus model pengajaran-Nya. ${ }^{11}$ Sejalan dengan hal tersebut, Professor George B. Stevens mengulas pengajaran Yesus, terkhusus dalam metode pengajarannya: teladan, tindakan, ataupun kisah, kiasan, metafora, pepatah, ataupun paradoksal. ${ }^{12}$ McCoy (2016) menambahkan model pengajaran Yesus dalam bentuk: story teller, ilustrasi, dialog, learning by doing, ataupun learning by example. ${ }^{13}$

Tentang pandangan di atas, di satu sisi, Siburian (2018) mengkritik pandangan analitik yang menarik tindakan pengajaran Yesus dalam perspektif pedagogi non-kristologi. Baginya, keistimewaan Yesus, tidak terletak pada profesionalitas guru sebab Yesus lebih merupakan guru kehidupan daripada guru kelas. Semua analisis yang berbasis point of view modern atau pedagogi non-kristologi hanya akan mereduksi eksistensi Yesus sendiri. Di sisi lain, Siburian menyetujui bahwa keagungan Yesus terletak pada pribadi dan status-Nya sebagai Allah yang berinkarnasi. Dimensi ilahi menjadi utama dalam segala pengajaran. ${ }^{14}$ Melalui tesisnya ini, Siburian menempatkan pemikiran kristologi sebagai jiwa pastoral, khususnya pendidikan agama.

\footnotetext{
8 Daniel Fajar Panuntun and Eunike Paramita, "Hubungan Pembelajaran Alkitab terhadap Nilainilai ( Kelompok Tumbuh Bersama Kontekstual )," Gamaliel : Teologi Praktika 1, no. 2 (2019): 104-115.

9 Binsen S Sidjabat, “Penguatan Guru PAK untuk Pendidikan Karakter :," Evangelikal: Jurnal Teologi Injili dan Pembinaan Warga Jemaat 3 (2019): 30-48; Musa Sinar Tarigan, "Implikasi Penebusan Kristus dalam Pendidikan Kristen [the Implication of Christ'S Redemption on Christian Education]," Polyglot: Jurnal Ilmiah 15, no. 2 (2019): 203, https://doi.org/10.19166/pji.v15i2.1409; Alfian Dwi Primantoro, "Pendidikan Nilai Moral Ditinjau dari Perspektif Global," JPK: Jurnal Pancasila dan Kewarganegaraan 1, no. 1 (2016): 1-8; Arozatulo Telaumbanua, "Peranan Guru Pendidikan Agama Kristen dalam Membentuk Karakter Siswa," FIDEI: Jurnal Teologi Sistematika dan Praktika 1, no. 2 (2018): 219-31, https://doi. org/10.34081/fidei.v1i2.9.

10 Made Astika dan Selvianty Sari Bunga, "Hubungan Kompetensi Sosial Guru Kristen terhadap Perkembangan Karakter Siswa: Tantangan Pendidikan Kristen dalam Mencerdaskan Youth Generation," Jurnal Jaffray 14, no. 1 (2016): 63, https://doi.org/10.25278/jj71.v14i1.189.

11 Fønnebø, L., "A Grounded-Theory Study of the Teaching Methods of Jesus: An Emergent Instructional Mode," Graduate Research no. 1, (2011): 32-41.

12 Stevens, G. B., “The Teaching of Jesus. II. The Methods of His Teaching," The Biblical World 5, no. 2 (1895): 106-113, The University of Chicago Press, https://www.jstor.org/stable/3135144.

13 McCoy, J. W., "The teaching methods of Jesus," The Journal of Biblical Foundations of Faith and Learning 1, no. 1 (2016): 1-16, https://knowledge.e.southern.edu/jbffl/vol1/iss1/9.

14 Siburian, T., "Perspektif Kristologis Mengenai “Yesus Guru Agung," Jurnal Teologi Stulos, no. 2 (Juli 2018): 179-206, http://sttb.ac.id/download/stulos/stulos-v16-no02/Stulos-Vol16-No-2-Perspektif Kristologis Mengenai Yesus Guru Agung.pdf.
} 
Implikasinya adalah bahwa pengajaran agama Kristen tidak boleh dilepaskan dari konteks keimanan. Pendidikan agama bukan semata-mata ranah kognitif (anak mengetahui), ranah psikologis (anak merasa) dan ranah tindakan (anak mempraktikkan), tetapi juga ranah keimanan (anak percaya).

Tentunya, telah banyak kajian tentang pendidikan agama Kristen yang berfokus pada Yesus. Namun, penulis menilai bahwa pembahasan langkah pembinaan berbasis iman dengan analogi imajinatif sangat potensial untuk digali dan ditelaah. Di sini, penulis meyakini bahwa Yesus membimbing para murid untuk mengalami iman dan bahwa pengalaman iman tersebut menjadi dasar pembentukan karakter para murid yang terwujud tindakan iman para rasul. Oleh karena itu, penelitian ini ingin menjawab kegelisahan edukatif tentang makna pedagogis dari pengajaran Yesus dalam kisah panggilan, langkah pendidikan atau pembinaan yang dilakukan oleh Yesus terhadap para murid-Nya, dan implementasinya dalam pendidikan agama Kristen.

Dalam rangka mencari jawab atas kegelisahan di atas, penulis menggunakan metode library research dalam penelitiannya. Dengan metode ini, penulis menggunakan kepustakaan sebagai basis pencarian data-data dalam berbagai sumber: buku, jurnal, website, dan tentunya, kitab suci. Berdasar data-data yang diperoleh, penulis merangkai gagasan untuk menyampaikan bahwa pendidikan agama Kristen adalah pengembangan diri berpangkal dari iman. Artinya, jika terlepas dari konteks iman kepada Yesus, pendidikan agama Kristen jatuh pada formalitas normatif yang kosong. Untuk itu, pertama-tama, penulis menegaskan pendidikan agama Kristen dalam pastoral atau sebagai implikasi kristologi. Lalu, analisis makna kisah (story) dilakukan untuk memberikan gambaran bahwa Yesus telah mengajarkan nilai dan membentuk pribadi para muridnya dan menginspirasi aspek-aspek pendidikan. Dengan penjelasan tentang Guru Yesus, kisah panggilan para murid akan diolah dan dianalisis untuk mengeksplorasi dan merumuskan langkah-langkah pembinaan pribadi yang dilakukan Yesus. Analogi imajinatif akan diangkat sebagai saripati metode atau langkah pembinaan atau pendidikan agama Kristen yang berbasis iman kepada Yesus.

\section{Diskusi dan Hasil}

Pendidikan Agama sebagai Tindakan Pastoral dan Implikasi Kristologi

Sebagaimana telah disinggung di awal, penelitian ini mendasarkan diri pada pemahaman kristologi dalam kaitannya dengan tugas gerejani (three fold mission of Christ), yaitu kenabian, imamat, dan raja. Kristologi menjadi pijakan untuk memahami posisi misiologi pastoral, yaitu katekese atau evangelization, di mana pendidikan agama menjadi ujung tombaknya. 
Kerangka ini tidak lain adalah refleksi iman dalam konteks bermasyarakat, khususnya pendampingan kaum muda.

Iman kepada Kristus Yesus berarti iman kepada Allah Bapa yang berinkarnasi dalam diri sang Allah Putra. Dalam kemanusiaan-Nya, Yesus Kristus pun diberkati oleh Bapa dan menerima tugas dalam jabatan imam, nabi, dan raja. ${ }^{15}$ Sebagai penerus-Nya, gereja pun mengemban tiga tugas jabatan tersebut. Sebagai imam, gereja menguduskan umat Allah melalui sakramen demi curahan rahmat Allah (lingkup ritual dan ibadat). Sebagai raja, gereja mengurus dan mengatur tata kehidupan jemaat dalam organisasi dan komunitas (lingkup persekutuan institusional). Sebagai nabi, gereja mewartakan kebenaran ilahi, yaitu karya keselamatan Allah melalui Yesus Kristus sehingga warisan kekayaan iman dapat diwariskan (evangelization dan katekese). Dalam kerangka tugas jabatan kenabian, pewartaan iman (dalam pendidikan agama) berarti tindakan pastoral (penggembalaan umat) yang selalu terhubung dan tidak terlepas dari Kristus Yesus. Pendidikan agama Kristen pun harus bersumber dan senantiasa menggali inspirasi dari Guru Yesus.

Keseluruhan tugas gerejani tersebut terungkap dalam Sabda Yesus: “...engkau akan menjala manusia" (Lukas 5: 10). Perikop ini menjadi dasar bagi perutusan rasul yang bersifat visioner-imajinatif dalam balutan kisah panggilan. Tentunya, perutusan ini menjalani pemurnian dan kejelasan perutusan dalam keseluruhan Kitab Suci, tetapi kisah panggilan menduduki tempat istimewa karena menjadi kunci pembuka bagi kisah-kisah selanjutnya. ${ }^{16}$ Lalu, bagaimana kedudukan kisah dalam pengajaran Yesus?

\section{Yesus sebagai Guru Agung yang Berkisah}

Pembinaan iman (atau pendidikan karakter kristiani) menjadikan Yesus sebagai sumber inspirasi. Hal ini ditegaskan oleh Markes dengan pendapatnya bahwa Sang Guru, Yesus Kristus, menjadi sumber nilai hidup dan bahwa Living Values Education hendaknya menjadi Christian Value Education. Baginya, sebuah pendidikan kristiani harus berangkat dari iman akan Yesus Kristus sebagai akar nilai-nilai kekristenan. Menghidupi nilai-nilai kekristenan tidak lain adalah kesetiaan dalam meneladani pribadi Yesus sendiri dalam tiga aspek: aku dan Tuhan; aku dan sesama; aku dan diriku. ${ }^{17}$

15 Katekismus Gereja Katolik (KGK) No. 783.

16 Dalam perjalanan mengikuti Yesus, para murid harus memahami jati diri Yesus sebagai Anak Allah sebagai ungkapan Petrus (Matius 16:13-20) dan tugas perutusan: “Karena itu pergilah, jadikanlah semua bangsa murid-Ku dan baptislah mereka dalam nama Bapa dan Anak dan Roh Kudus, dan ajarlah mereka melakukan segala sesuatu yang telah Kuperintahkan kepadamu." (Matius 28:19-20)

17 Karlito D Markes, “Living Values Education dan Implikasinya bagi Pendidikan Agama Kristen,” 
Sunarko menegaskan posisi Yesus sebagai sosok guru. Dalam kajiannya, Yesus dipandang sebagai seorang pengajar yang juga sering disapa sebagai rabi di dalam Alkitab, baik oleh para pengikut-Nya, maupun juga oleh orang Farisi sebagai orang yang menentang-Nya. Kata rabi pun merupakan gelar kehormatan di masa itu yang digunakan untuk menyebut guru yang khusus mengajar tentang agama atau Torah Yahudi. Kata rabi ditulis empat kali dalam Injil Matius (23:7,8; 26:25,49), tiga kali dalam Injil Markus (9:5; 11:21; 14:45), dan delapan kali dalam Injil Yohanes $(1: 38,49 ; 3: 2,26 ; 4: 31$; $6: 25 ; 9: 2 ; 11: 8)$. Yesus tidak suka dipanggil rabi atau guru. Namun, dalam pelaksanaan tugas-Nya, Yesus membimbing dan mengajar para murid..$^{18}$

Kitab suci lebih banyak mengisahkan Yesus yang tampil sebagai guru pada usia dewasa dengan pengantar pada kisah Yesus di usia 12 tahun di mana Yesus sudah dikenal sebagai anak yang cerdas di antara alim-ulama di sinagoge. Kisah Yesus di sinagoge (Lukas 2: 41-52) menjadi pembukaan tentang Yesus sebagai Guru Agung. Dia sebagai guru tampil di Galilea (Lukas 4: 14-15) dan mengajar di rumah ibadat dengan berbagai tema: bertobatlah sebab "kerajaan Surga sudah dekat" (Matius 4: 12-17) dan "waktunya sudah genap" (Markus.1: 14-15). Ia memilih dua belas orang yang secara khusus menjadi murid-Nya (Matius 4: 18-22; Matius 1: 16-20; Lukas 5: 1-11), dengan tetap mengingat murid-murid lain di luar dua belas rasul tersebut.

Sebagai guru, Yesus menggunakan banyak cara dan corak pengajaran: ceramah "Khotbah di Bukit" (Matius: 1-12; Lukas 6: 20-23); analogi "Garam dan Terang Dunia" (Matius 5: 13-16); dan pesan-pesan Lukas 22: 24-38). Perumpamaan pun digunakan dalam pengajaran: seorang penabur, lalang di antara gandum, biji sesawi dan ragi, harta dan mutiara (Matius 13: 1-58), domba hilang (Matius 18: 12-14), pengampunan (Matius 18: 21-35), upahan di kebun anggur (Matius 20:1-16), perjamuan kawin (Matius 22: 1-13). Selain itu, Yesus melakukan pengajaran dalam tindakan, seperti: penyembuhan (konteks kondisi) (Matius 8:1-4; 5-13; 14-17), tindakan berupa pengutusan murid (Matius 10: 5-15), kisah memberi makan lima ribu orang (Matius 14: 13-21), serta keteladanan (Lukas 22: 26).

Yesus mengajarkan berbagai materi dan pengajaran: moral seperti bersedekah (Matius 6: 1-4), peribadatan dan rohani, tentang berdoa, dan Doa Bapa Kami (Matius 6: 5-13), laku tapa seperti berpuasa (Matius 6: 16-18; 9: 14-17), pengalaman/rasa tentang kekhawatiran (Matius 6: 25-30), sikap dan tindakan seperti menilai (Hal menghakimi (Matius: 7: 1-5), jalan yang benar (Matius 7: 12-14), sikap seorang murid (Matius 8: 18-22), serta

\footnotetext{
Manna Rafflesia 6, no. 2 (2020): 220-40, https://doi.org/10.38091/man_raf.v6i2.120.

18 Andreas Sese Sunarko, "Implikasi Keteladanan Yesus Sebagai Pengajar bagi Pendidikan Kristen yang Efektif di Masa Kini," REGULA FIDEI: Jurnal Pendidikan Agama Kristen 5, September (2020): 118-31.
} 
pemahaman hukum seperti makna hari Sabat (Matius 12: 9-14). Ia juga mengajarkan masa depan dan visi hidup, seperti pemberitahuan tentang penderitaan (Matius 17: 22-23), kebangkitan hidup (Matius 22: 23-33), dan akhir zaman (Matius 24-25).

Atas pengajaran-Nya, banyak pihak mengakui status-Nya sebagai Guru. ${ }^{19}$ Mereka adalah a) para rasul (Lukas 17:13) dengan ucapan: "Yesus, Guru, kasihanilah kami!", b) ahli taurat dengan "Guru, jawab-Mu itu tepat sekali" (Lukas 20:39), c) pengajuan Farisi (Lukas 19:39), d) pengajuan orang biasa (Lukas 9:38), e) pemungut cukai (Lukas 3:12), dan f) pemimpin politik: "Guru yang baik, apa yang harus aku perbuat untuk memperoleh hidup yang kekal?" (Lukas 18:18). Secara khusus, pengakuan para rasul mengalami puncak sebagaimana diwakili oleh pengakuan Simon Petrus, bahwa Yesus yang selama ini adalah Guru, juga adalah Anak Allah yang hidup (Matius 16: 15). Pengakuan Petrus adalah pengakuan spiritual terhadap sang Guru yang adalah Anak Allah. Kesadaran spiritual hadir melalui pemahaman atas kisah yang sudah diterima para rasul di masa lalu dan sekaligus mempersiapkan tugas kerasulan di masa depan.

Kisah hidup Yesus adalah kisah seorang Guru Agung (inkarnasi Allah sendiri). Sebagai seorang guru, Tuhan Yesus adalah teladan sempurna. Tuhan Yesus bukan hanya memberikan perintah yang harus ditaati oleh gereja-Nya terlebih oleh hamba-hamba-Nya yang dipercaya untuk menggembalakan umat-Nya supaya melaksanakan tugas penggembalaan dan pengudusan, tetapi juga tugas pengajaran sebab, “... murid tidak lebih daripada gurunya, tetapi barangsiapa yang telah tamat pelajarannya akan sama dengan gurunya" (Lukas 6:40). Maka, perintah, "Ikutlah Aku!" (Matius 4: 19) merupakan perintah Guru dan Tuhan dengan memperhatikan ketentuan: "Setiap orang yang mau mengikut Aku, ia harus menyangkal dirinya, memikul salibnya setiap hari dan mengikut Aku" (Lukas 9:23) dan sebaliknya, "Barangsiapa tidak memikul salibnya dan mengikut Aku, ia tidak dapat menjadi murid-Ku" (Lukas 14:27) sebab "Barangsiapa tidak memikul salibnya dan mengikut Aku, ia tidak layak bagi-Ku" (Matius 10:38).

Kisah Guru Agung, Yesus Kristus, menjadi model pemuridan sebagai konsekuensi atas panggilan hidup. Yesus mengajar dan membimbing para murid, bukan hanya menyampaikan warta Kerajaan Allah, tetapi juga membuka wahyu diri Yesus sebagai Anak Allah. Richard Peace dalam Eldin Villafane berkata, "As the Master, so the disciples. The pattern which the Son of Man will live out is the pattern that his disciples must follow". Demikianlah, pola yang akan dijalankan Anak Manusia adalah pola yang harus diikuti oleh

19 Yesus sendiri memberikan peringatan tentang kebanggaan orang dengan sebutan guru (Mat. 23: 8) 
para muridnya..$^{20}$ Yesus adalah guru yang mengajar, tetapi bukan dalam konteks keguruan tetapi dalam konteks keselamatan Allah, yaitu Allah yang mencintai, hadir dan berinkarnasi, serta rela menderita, sengsara, dan wafat demi keselamatan manusia. Artinya, pribadi dan hidup Yesus sendirilah yang terutama dalam pengajaran dan pendampingan para rasul. Dengan demikian, kisah memainkan peranan penting dalam pengajaran Yesus.

\section{Kisah (Story) dalam Pendidikan Karakter dan Nilai}

Sebagai salah satu pilar pendidikan karakter bangsa khususnya dalam pembinaan iman, ${ }^{21}$ pendidikan agama Kristen harus mempersiapkan generasi penerus bangsa yang memahami dan mengamalkan nilai-nilai ajaran agamanya. ${ }^{22}$ Artinya, nilai dan karakter menjadi bagian kajian dalam pendidikan agama Kristen. Yang menarik adalah bahwa Alkitab (sebagai dasar iman kristianitas) merupakan kisah tindakan dan karya Allah yang mencintai dan menebus manusia. Lalu, apa pentingnya kisah?

Pertama, kisah membangkitkan imaji. Mengenai kekuatan cerita atau kisah, Terrence Gargiulo telah menuangkan gagasan pedagoginya tentang cerita (storytelling). Dia menegaskan adanya hubungan antara cerita dan pengalaman. Cerita atau kisah merupakan alat pengait atau alat pengangkut (stimulator) atas pengalaman seseorang dari dalam dirinya. Dengan kisah, peserta atau pendengar akan diajak untuk keluar dari dirinya sendiri yang nyaman. Dalam mendengarkan kisah, orang sejenak lupa akan dirinya dan masuk untuk ikut mengambil bagian dalam kisah. Mengapa demikian? Hal itu terjadi karena kemampuan daya bayang atau imaji orang. Kisah rupanya mampu menyentuh kemampuan tersebut. Pada saat kisah berjumpa dengan imaji, seseorang dimungkinkan untuk keluar dari diri dan masuk dalam kisah. Kemampuan daya bayang mampu membawa aku untuk mengalami kisah sebab hanya kisah yang mampu menyentuh imaji dan menyeret $a k u$ ke dalamnya. ${ }^{23}$

Kedua, kisah menciptakan pengalaman baru. Penulis menyadari bahwa imaji menempati kamar privat bagi seseorang dan kisah yang diceritakan membawa pendengar untuk keluar dari ke-diri-annya dan masuk dalam cerita serta mengalami peristiwa cerita itu. Mengalami cerita (yang bukan kisahku) merupakan imitasi imajinatif yang membuat pendengar sejenak

20 Sari Saptorini, "Pemanggilan Murid Secara Sengaja Berdasarkan Teladan Tuhan Yesus," PASCA: Jurnal Teologi dan Pendidikan Agama Kristen 15, no. 1 (30 November 2019): 35-43, https://doi.org/10.46494/ psc.v15i1.67.

21 Abuddin Nata, "Peran Pemuda dalam Sektor Pendidikan," UIN Jakarta, 2020, uinjkt.ac.id.

22 Presiden Republik Indonesia, “Undang-Undang Republik Indonesia Nomor 12 Tahun 2012 tentang Pendidikan Tinggi," 2012. Bab I. Ketentuan Umum, Pasal 3-5

23 Bel Silberman, Handbook of Experiential Learning, Pfeiffer I (San Francisco: Pfeiffer, 2007), 256. 
berjarak dengan diri tetapi sekaligus mengenali pengalaman diri dalam cerita. ${ }^{24}$

Ketiga, kisah menghadirkan makna yang berbalut peristiwa. Pendasaran kekuatan cerita ini berada pada keyakinan bahwa pengalaman adalah ingatan yang terekam dan tersimpan dalam bentuk kisah atau cerita, yang membentuk persepsi (sikap, nilai-nilai, keyakinan, asumsi) yang menuntun tingkah laku. Jadi, kisah bukanlah sekadar urutan kejadian, tetapi makna yang terselip dalam sebuah rangkaian peristiwa. Artinya, kisah menyampaikan makna dan nilai dan karenanya mampu membentuk pemaknaan suatu peristiwa yang dialami. Kisah menghadirkan pertemuan personal. Melalui kisah, aku berjumpa dengan dia secara personal. Dengan demikian, para murid pun dapat memahami mengapa Yesus banyak menggunakan kisah dalam menyampaikan ajaran-Nya. Melalui cerita atau kisah, Guru Yesus tidak sekadar menyampaikan informasi atas suatu kejadian. Ia menawarkan makna dan nilai melalui kisah yang dialami pendengarnya. Dengan kisah atau cerita pula, pendengar mudah mengalami dan menyadari hidupnya karena mereka masuk dalam kisah dan maknanya. ${ }^{25}$

Keempat, kisah menyediakan ruang kekayaan hermeneutika ajaran. Pandangan ini bercermin dari gagasan Noh Ibrahim Boiliu dkk. ${ }^{26}$ Paradigma kisah digunakan dalam paparan Noh Ibrahim Boiliu dkk untuk mengupas pendidikan nilai pada pengajaran Khotbah di Bukit (Matius 5 : 6-12). Para penulis tersebut menggunakan kisah untuk menguak makna haus dan lapar (Matius 5: 6). Inilah kisah di belakang ungkapan atau ajaran. Dengan kisah yang berbeda, Noh Ibrahim Boiliu menemukan makna berbeda pula, misalnya kisah penindasan dan pembebasan kaum tertindas yang dialami bangsa Israel, atau kisah sejarah keselamatan yang dibangun bangsa Israel sesuai pandangan France, Newman dan Stine, atau Osborne sehingga haus dan lapar tidak berarti fisik tetapi lebih rohani, yaitu haus dan lapar akan firman Allah. ${ }^{27}$ Dalam hal ini, kisah yang hadir sebagai paradigma memberikan kekayaan makna atas suatu ajaran.

Kelima, kisah rupanya hadir atau bahkan dapat diciptakan untuk pengajaran. Untuk menyampaikan maksud dan ajaran-Nya, Yesus menciptakan peristiwa yang harus dialami oleh para murid-Nya. Dengan peristiwa tersebut, para murid menyadari siapa Yesus itu. Kisah mukjizat lima roti dan dua ikan (Matius 14:13-16) merupakan kehadiran sebuah

\footnotetext{
$24 \quad$ Ibid., 256.

25 Silberman, Handbook of Experiential Learning, 255-257.

26 Ibrahim Boiliu et al., "Mengajarkan Pendidikan Karakter Melalui Matius 5: 6-12," KURIOS: Jurnal Teologi dan Pendidikan Agama Kristen 6, no. 1 (2020): 61-71.

27 Ibid., 63-64.
} 
peristiwa demi pengajaran yang menghentak karena tugas yang tidak masuk akal. Tanpa banyak bekal, para murid harus memberi makan lima ribu laki-laki, tidak termasuk perempuan dan anak-anak. ${ }^{28}$ Tetapi, kemustahilan tersebut dinegasi dengan kenyataan: "Mereka semuanya makan sampai kenyang. Kemudian, orang mengumpulkan potongan-potongan roti yang tersisa sebanyak dua belas bakul penuh" (Matius 14: 20). Peristiwa mukjizat merupakan kisah yang sengaja diciptakan Yesus untuk suatu pengajaran bagi para murid.

Keenam, kisah bersifat imperatif-transformatif. Kisah perjamuan terakhir bukanlah peristiwa spontanitas. Dengan sengaja, Yesus mengadakan perjamuan bersama para murid di akhir hidup-Nya. Yang menarik dari kisah ini adalah bahwa makan bersama (memotong dan membagi roti) menyadarkan dua murid yang berjalan ke Emaus (Lukas 24: 13-33). Mereka terbuka mata dan kesadarannya saat Yesus mengambil roti, mengucapkan berkat, dan memecahkan roti serta memberikan roti kepada dua murid tersebut (Lukas 24: 30-31). Karena pengalaman tersebut, bangunlah mereka dan terus kembali ke Yerusalem (Lukas 24: 33). Kisah perjamuan terakhir bukan hanya sekadar peristiwa tetapi pengalaman yang memerintahkan dua murid untuk berbalik arah: dari Emaus ke Yerusalem, dari kedukaan ke kegembiraan, dari bersungut-sungut ke pewartaan, dari ketakutan ke keberanian, dari pemisahan diri ke komunitas rasuli.

Dengan uraian di atas, penulis menegaskan bahwa kisah mampu memerintah dan membuat perubahan mendasar bagi murid-Nya. Dengan demikian, kisah menjadi kekuatan imperatif-transformatif bagi pribadi dan karakter. Kisah mampu menghadirkan pengalaman dan memberikan makna atas peristiwa, bahkan membimbing dan memberikan daya dorong perubahan.

\section{Kisah Panggilan Sang Murid}

Pada bagian ini, penulis ingin menganalisis satu kisah sederhana, yaitu kisah panggilan (Matius 4: 18-22, Markus. 1: 16-20, Lukas 5: 1-14) yang menceritakan Yesus memanggil para murid, khususnya Simon (Petrus), Andreas, Yakobus dan Yohanes (saudara Yakobus). Analisis dilakukan atas ketiganya tanpa bermaksud membandingkan untuk membuat penilaian, tetapi ketiga kisah diharapkan menjadi paparan kisah paralel yang dapat memperkaya. Kisah panggilan dalam Injil Sinoptik ini cukup pendek dan dapat dikelompokkan dalam beberapa versi.

\footnotetext{
28 Talizaro Tafonao, "Penerapan Strategi Pengajaran Tuhan Yesus terhadap Pencapaian Tujuan Pendidikan Agama Kristen," AgriXiv (April 2019): 120-35, https://doi.org/10.31220/osf.io/a4b76.
} 
Pertama, dalam Matius dan Markus terdapat urutan kejadian mengenai perjumpaan, perintah untuk mengikuti, visi (menjadi penjala manusia), dan aksi untuk mengikuti. Kedua, Lukas menyajikan kisah dengan rangkaian kejadian yang jauh lebih panjang: pengajaran (kelompok besar), mukjizat (pengajaran kelompok kecil), takjub, pertobatan (yang diwakili Petrus), nasihat dan visi hidup ("Jangan takut, mulai dari sekarang engkau akan menjadi penjala manusia" Lukas 5: 10), tindakan aktif (dalam bentuk: mengikuti Yesus). Untuk lebih jelasnya, kisah panggilan dibagi dalam kedua versi seperti disajikan berikut:

Tabel 1. Tabel Komparasi Kisah Panggilan Rasul

\begin{tabular}{|c|c|c|c|c|}
\hline \multirow[t]{2}{*}{ No. } & \multirow{2}{*}{$\begin{array}{c}\text { Matius dan } \\
\text { Markus }\end{array}$} & \multirow[t]{2}{*}{ Lukas } & \multicolumn{2}{|c|}{ Jenis Tindakan } \\
\hline & & & $\begin{array}{l}\text { Matius \& } \\
\text { Markus }\end{array}$ & Lukas \\
\hline 1. & $\begin{array}{l}\text { Yesus berjalan } \\
\text { menyusuri } \\
\text { danau Genezaret, } \\
\text { melihat Simon } \\
\text { dan Andreas }\end{array}$ & $\begin{array}{c}\text { Yesus berdiri } \\
\text { menghadapi orang } \\
\text { banyak; menaiki } \\
\text { (menaiki apa?) dan } \\
\text { duduk }\end{array}$ & Berjalan & Berdiri \\
\hline 2. & - & $\begin{array}{l}\text { Melakukan } \\
\text { pengajaran }\end{array}$ & - & Pengajaran \\
\hline 3. & - & $\begin{array}{l}\text { Menyuruh Simon } \\
\text { bertolak ke tempat } \\
\text { yang lebih dalam } \\
\text { dan menebar jala }\end{array}$ & - & Perintah \\
\hline 4. & - & $\begin{array}{c}\text { Mendapat } \\
\text { banyak tangkapan } \\
\text { (mukjizat) }\end{array}$ & - & Mukjizat \\
\hline 5. & - & $\begin{array}{l}\text { Simon dan semua } \\
\text { orang takjub }\end{array}$ & - & Kagum \\
\hline 6. & - & $\begin{array}{l}\text { Simon bertobat } \\
\text { (merasa berdosa) }\end{array}$ & - & Bertobat \\
\hline 7. & $\begin{array}{c}\text { "Mari Ikutlah } \\
\text { Aku!" }\end{array}$ & $\begin{array}{l}\text { Yesus menasihati } \\
\text { (Jangan takut!) }\end{array}$ & Perintah & Nasihat \\
\hline 8. & $\begin{array}{c}\text { "Kamu akan } \\
\text { Kujadikan } \\
\text { penjala manusia" }\end{array}$ & $\begin{array}{l}\text { Mulai sekarang } \\
\text { kamu akan } \\
\text { menjadi penjala } \\
\text { manusia }\end{array}$ & Keputusan & Pemberitahuan \\
\hline
\end{tabular}




\begin{tabular}{|c|c|c|c|c|}
\hline 9. & $\begin{array}{c}\text { Mereka } \\
\text { mengikut Yesus }\end{array}$ & $\begin{array}{l}\text { Simon mengikuti } \\
\text { Yesus dan } \\
\text { meninggalkan } \\
\text { segala sesuatu }^{29}\end{array}$ & Keputusan & Keputusan \\
\hline
\end{tabular}

\section{Sumber: Analisis Peneliti}

Dari tiga narasi dalam dua versi di atas, terlihat tindakan Yesus dan respons pendengar (Simon Petrus dkk) yang berbeda. Perbedaan kisah panggilan ini dapat dimengerti jika menyadari kepentingan, pesan, pendengar, dan maksud penulis dalam kerangka keseluruhan kisah. Walaupun terdapat perbedaan (yang tidak harus dipertentangkan), kisah awal panggilan para murid ini saling melengkapi dan dapat menjadi sebuah konfigurasi panggilan murid dan proses pewahyuan diri Yesus.

Pertama, konteks pendengar. Danau Genesaret merupakan konteks yang diperhatikan. Yesus memperhatikan, memahami, dan menggunakan situasi pendengar: menyusuri danau, perahu, jala, ikan. Kedua, komunitas atau kelompok. Lukas memunculkan aktivitas komunitas sebagai narasi antisipatif atas pembentukan komunitas dua belas rasul sebagai satu kesatuan dan Petrus dipersiapkan sebagai pemimpinnya.

Ketiga, mukjizat. Lukas menceritakan Yesus melakukan mukjizat yang juga diambil dari konteks pendengar, yaitu kegiatan menjala ikan. Hal menarik di sini adalah bahwa aktivitas Yesus sangat biasa, tetapi dilakukan dengan luar biasa karena latar belakang pendengar (semalam-malaman mereka tidak mendapat ikan, padahal mereka adalah nelayan profesional) dan identitas Yesus sebagai orang yang bukan nelayan (tetapi Yesus memerintah dengan percaya diri dan berhasil menangkap ikan). Secara manusiawi, perintah Yesus sulit diterima karena merekalah yang paham dunia nelayan. Menanggapi perintah Yesus, para nelayan itu seharusnya menolak atau bahkan mendebat sikap Yesus. Tetapi, sekali lagi, kisah mukjizat ini berada dalam kerangka iman. Karena itu, perintah Yesus harus dipahami dalam konteks iman, yakni siapa Yesus sebenarnya. Dalam segala peristiwa mukjizat ini, Yesus mewahyukan diri-Nya dan menunjukkan kualitas diri-Nya sehingga ditanggapi oleh para nelayan dalam pengalaman mereka.

Empat, pengalaman. Dalam perspektif kristologi, Lukas meletakkan mukjizat sebagai pintu bagi pewahyuan diri Yesus dan terciptanya pengalaman batin para murid. Pengalaman takjub yang dialami pendengar (Simon Petrus dan lainnya) adalah pengalaman intelektual (di mana dengan komprehensif, mereka mengetahui aktivitas menangkap ikan) dan terlebih

29 Pola berulang terhadap Yakobus dan Yohanes. 
pengalaman batin (yang membuat Simon Petrus sadar siapa dirinya dan siapa Dia). Dalam kepercayaan tanpa pertanyaan, Petrus bertindak. Pengalaman batiniah menggerakkan Petrus untuk mempercayakan diri kepada Yesus. Artinya, sebuah sikap iman sudah tumbuh ketika Petrus mengatakan, "karena Engkau menyuruhnya, aku akan menebarkan jala juga"

Kelima, visi hidup. Pembentukan visi sebagai transformasi paradigma. Matius, Markus, dan Lukas, secara implisit, menyajikan pola pararel: Allah berinkarnasi dalam diri Yesus dan menjalankan tugas perutusan memberitakan keselamatan Allah bagi manusia. Demikianlah, Yesus memanggil para murid untuk "berinkarnasi" dengan mentransformasi diri melalui visi perutusan, yaitu menjadi penjala manusia. Visi perutusan tersebut harus mendapat persetujuan dalam bentuk keputusan para rasul, sebagaimana ditemukan di akhir kisah panggilan (baik dalam Matius, Markus, dan Lukas). Sebagai catatan, keputusan para rasul ini akan menjadi nyata dan terpenuhi dalam hidup para rasul sendiri.

Lima konfigurasi (konteks pendengar, komunitas, mukjizat, pengalaman, visi hidup) dapat ditempatkan dalam beberapa bagian, yaitu kejadian, makna, dan aspek pedagogi. Tabel kisah tersebut disajikan berikut ini:

Tabel 2. Tabel Pemaknaan Proses Panggilan Para Rasul ${ }^{30}$

\begin{tabular}{|c|c|c|c|}
\hline Bagian & Kejadian/Peristiwa & Makna & Aspek Pedagogi \\
\hline Konteks Alam & Lingkungan & Pemahaman & Aspek Kognitif \\
\hline $\begin{array}{c}\text { Konteks } \\
\text { manusia }\end{array}$ & Pengikut, pendengar & Tenggang rasa & Aspek Afektif \\
\hline Komunitas & Orang-orang & Berbagi Pengalaman & Aspek Sosial \\
\hline Mukjizat & Menjala ikan & Tindakan, aktivitas & Aspek Psikomotorik \\
\hline Pengalaman & Mukjizat & $\begin{array}{c}\text { Pengalaman } \\
\text { adikodrati }\end{array}$ & Aspek Spiritual \\
\hline Visi Hidup & Visi & Arah Langkah & Aspek imajinasi \\
\hline
\end{tabular}

Sumber: Hasil Analisis Peneliti

Dari paparan di atas, kisah panggilan menyimpan enam aspek yang terjadi dalam perjumpaan Yesus dan murid-murid pertamanya. Keenam aspek tersebut kiranya menjadi sebuah tahapan pengenalan dan sekaligus pengajaran. Kisah tersebut telah melukiskan sebuah perjumpaan dengan

30 Dibuat berdasarkan kejadian, makna, aspek pedagogi. 
intensitas yang semakin kuat. Artinya, terjadi dinamika input-output dan proses internal (black box $)^{31}$ dalam proses dialog Yesus dan rasul. ${ }^{32}$

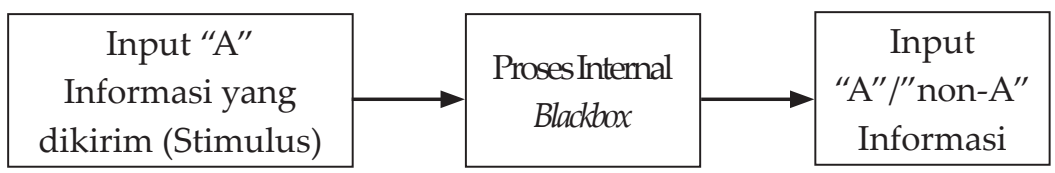

\section{Diagram 1. Diagram Komunikasi Input-Output}

Sumber: Tabel dari Buku "Model Pembelajaran Pendidikan Nilai", hlm. 19

Yesus memperhitungkan aspek-aspek komunikasi sehingga para murid dapat menangkap pesan yang disampaikan. Dengan demikian, Yesus mempunyai kompetensi dalam menyampaikan pesan dengan cara dan langkah pendidikan. Dalam kisah, penggunaan lingkungan (danau, perahu, ikan, jala) atau kegiatan menangkap ikan dengan hasil tangkapan yang di luar nalar menunjukkan persiapan yang dilakukan Yesus atas pesannya (yaitu menjadikan nelayan sebagai murid yang akan menjala manusia). Untuk itu, para murid pun siap menerima visi: menjala manusia. Tanpa persiapan yang tepat, pemahaman visi pemuridan ini tidak mudah untuk diterima karena merupakan suatu aktualisasi diri seperti dalam pemahaman Abraham Maslow. ${ }^{33}$ Kesiapan ini terjadi karena pilihan yang tepat sesuai konteks tentang pesan utama Yesus, yaitu analogi imajinatif. ${ }^{34}$

\section{Analogi imajinatif: Metode Pengembangan Visi Religius}

Analogi sebagai Pilihan Pengajaran Yesus

Yesus tidak secara eksplisit menyatakan analogi. Tindakan-tindakan Yesus menyiratkan suatu analogi. Sebelum melangkah lebih jauh, KBBI mengartikan analogi dengan pengertian: "persamaan atau persesuaian dua benda atau hal yang berlainan" atau "kesesuaian sebagian ciri antara

31 Istilah black box sebenarnya merupakan metode pengujian sistem program (perangkat lunak) untuk mengetahui validitas suatu program. Black Box Testing menguji adakah kesalahan dalam proses program: dari data input sampai data output-nya. Bdk. Umi Hanifah, Ronggo Alit, dan Sugiarto Sugiarto, "Penggunaan Metode Black Box pada Pengujian Sistem Informasi Surat Keluar Masuk," SCAN: Jurnal Teknologi Informasi dan Komunikasi 11, no. 2 (2016): 33-40, http://ejournal.upnjatim.ac.id/index.php/scan/ article/view/643. Pola kerja black box testing ini digunakan oleh Prof. Kama Abdul Hakam dalam konteks komunikasi, yaitu bahwa data yang masuk ke diri (pesan ke otak) akan diproses oleh otak (semacam program) sebagai data yang diterima (penangkapan). Dalam proses ini, sebuah pesan akan diterima sama atau berkurang karena adanya pesan yang hilang. Hilangnya pesan tergantung pada beberapa faktor: sumber informasi, sifat informasi, saluran atau cara penyampaian, sifat penerima informasi (sikap, kesiapan diri, dll), respon dan interpretasi pesan.

32 Kama Abdul Hakam, Model Pembelajaran Pendidikan Nilai (Bandung: CV. Yasindo Multi Aspek, 2010), 18-20.

33 Abraham H. Maslow, Religion, Value, and Peak-Experiences (Columbus: Ohis State University Press, 1964), 8.

34 Mirza Alvira, Nur Hidayah, dan Chusniah, "Penerapan Model Analogi untuk Melatih Keterampilan Berpikir Kreatif Calon Konselor," Jurnal Pendidikan 4, no. 1 (2016): 758-764. 
dua benda atau hal yang dapat dipakai untuk dasar perbandingan"35 Di sini, analogi berarti adanya dua hal yang mempunyai persamaan dan kesesuaian, yang terhubung atau dihubungkan untuk maksud tertentu. Dalam kata kerjanya, menganalogikan berarti membandingkan dua hal atau sesuatu untuk menemukan kesamaan dan kesesuaian.

Di dalam kisah, ada teks dan $a k u .{ }^{36}$ Pada saat seseorang membaca sebuah kisah, pembaca akan bertemu dan berdialog dengan apa yang dibaca. Perjumpaan keduanya menghadirkan "dunia baru". Dunia baru ini tidak lain adalah kesadaran diri, atau Ricoeur menyebutnya sebagai pemahaman diri. Terhadap dunia baru, aku turut menyumbangkan kisahku dan teks pun turut mendermakan kisahnya. Persatuan kisahku dan kisah teks terjadi karena adanya persamaan dan kesesuaian dalam sebagian kisahku dan kisah teks. Dalam perjumpaan tersebut, bagian kisah yang sama akan melebur sehingga kisahku juga adalah kisah teks dan demikian pula sebaliknya. ${ }^{37}$

Analogi mampu meleburkan dua kisah; tidak seluruhnya tetapi hanya sebagian saja. Seorang pribadi (si $a k u$ ) sadar bahwa sebuah pemahaman (pandangan dunia) bukanlah milikku karena ada teks yang menyumbangkan perannya. Dengan begitu, aku tidak memegang kendali atas dunia baru, tetapi juga tidak dapat menghilangkannya. Namun, kondisi ini mendorong daya kreatif sebab kisahku (pengalaman, pandangan, pemikiran) diperkaya oleh kisah teks yang sebenarnya tidak aku punyai. Haryatmoko mengambil istilah transfiguratif dari Ricoeur serta fusion of horizon (peleburan cakrawala) dari Gadamer soal pemahaman diri dalam perpaduan dua dunia (aku dan teks) tersebut. ${ }^{38}$

Penulis melihat bahwa analogi menjadi kata kunci dalam memahami kisah Yesus, sang Guru Agung, dalam pengajaran-pengajaran-Nya. Bentuk eksplisit analogi adalah perumpamaan dan cerita yang digunakan dalam pengajaran. Bentuk implisit analogi adalah ajaran-ajaran verbal dan berbagai tindakan-tindakan antisipatif Yesus. Dalam konteks kisah panggilan murid, Yesus menggunakan analogi dalam peristiwa menjala ikan dengan hasil yang di luar nalar (karena begitu banyaknya ikan). Hal yang sama terjadi saat Yesus mengucapkan, "Jangan takut, mulai dari sekarang engkau akan menjala manusia" (Lukas 5: 10). Yesus melakukan analogi dengan kata menjala dalam menjala ikan dan menjala manusia.

35 KBBI, “Kamus Besar Bahasa Indonesia,” KBBI, diakses 20 Maret 2021, https://kbbi.web.id/analogi.

36 Teks di sini dapat berarti naskah, cerita, kejadian, peristiwa, atau segala hal yang ada di luar diri manusia. Pada saat menghadapinya, manusia dikatakan 'menghadapi teks'. Istilah 'aku' di sini berarti manusia itu sendiri yang dapat berperan sebagai pelaku, pembaca, pendengar, dan sebagainya.

37 Haryatmoko, "Analogi Permainan Ricoeur dalam Imajinasi Sastra: Imajinasi Melampaui Sangkar Moral," BASIS, (2005): 13-18.

38 Haryatmoko, Analogi Permainan Ricoeur, 1-3. 
Imaji dalam Penyampaian Tugas Perutusan

Lukas 5: 1-11 berisi kisah panggilan sebagai alur cerita utama. Tetapi, di dalamnya, Yesus memanggil murid tetapi sekaligus mengutus mereka, yaitu dalam ungkapan "...engkau akan menjala manusia" (Lukas 5: 10). Pengutusan ini pastinya tidak sepenuhnya dipahami oleh para murid sebab merupakan perutusan-antisipatif di mana kepenuhannya akan terjadi di akhir kisah Yesus. Tetapi, inilah pola analogi yang dilakukan Yesus: nelayan menjala ikan dan rasul menjala manusia. Jelas bahwa dunia rasul berbeda dengan dunia nelayan dan bahwa ikan pun berbeda dengan manusia. Walaupun berbeda, kedua dunia disatukan dalam kesamaan menjala. Dunia nelayan menjadi lebih kaya karena makna baru yaitu dunia kerasulan di mana dunia rasul mudah dijelaskan dengan menggunakan dunia para nelayan. Sementara itu, menjala telah menciptakan (create, creation) jembatan kedua dunia dalam imaji (daya bayang). Imaji (imajinatif, kata sifat) merupakan daya bayang, yaitu kemampuan untuk menciptakan kisah-kisah dalam pikiran yang berdasar pada data kondisi tertentu. Dalam psikologi, imaji atau imajinasi merupakan kemampuan merekonstruksi segala sesuatu, entah reproduktif ataupun produktif. Reproduktif berarti menerima, memahami, dan mencetak ulang data sesuai dengan informasi data yang diberikan. Produktif berarti menerima memahami, serta mencipta ulang melampaui informasi yang diberikannya. Dalam hal ini, imaji tentunya mengenakan perspektif produktif: imaji berati mencipta (create).

Dalam hermeneutika, imaji (creation) itu dipahami sebagai kemampuan memahami secara analogic. Heidegger melihat bahwa memahami bukanlah menangkap sesuatu di masa lalu yang statis. Baginya, memahami berarti menangkap sesuatu demi masa depan. Memahami berorientasi masa depan, bukan masa kini, atau bahkan masa lampau. ${ }^{39}$ Ia mendahului yang ada (sekarang) untuk menjadi aktual di masa depan. ${ }^{40}$ Heidegger berkeyakinan bahwa memahami berorientasi pada masa depan dengan membuka kemungkinankemungkinan kisah yang nanti akan terjadi. ${ }^{41}$ Dengan demikian, walaupun perjumpaan Yesus dan rasul terjadi di awal karya-Nya, namun makna perjumpaan akan membuka berbagai kemungkinan kisah dan memungkinkan hadirnya berbagai alur kisah dalam pikiran dan hati rasul. Artinya, bagi Heidegger, "memahami selalu visioner." ${ }^{22}$ Visioner berarti menarik masa depan ke waktu kini atau melemparkan kondisi kini ke masa depan yang

\footnotetext{
39 F. Budi Hardiman, "Seni Memahami Hermeneutik dari Schleiermacher Sampai Derrida," (Yogyakarta: Kanisius, 2015), 127.

40 Ibid, 121.

41 Ibid., 120.

$42 \quad$ Ibid., 122.
} 
tentunya tidak secara faktual. Karena itu, visioner berarti tindakan yang mendahului fakta sebab menghadirkan sesuatu yang belum terjadi kini. Mendahului fakta, bagi Heidegger, adalah memproyeksikan maknanya ke masa depan. ${ }^{43}$ Inilah pemahaman imaji dalam penelitian ini.

Dalam pemahaman imaji tersebut, nelayan dan aktivitasnya digunakan Yesus untuk menyampaikan maksud-Nya, yaitu bahwa para rasul akan menjala manusia. Dalam ungkapan tersebut, Yesus telah menarik dan menghadirkan tugas perutusan yang nanti akan menjadi tanggung jawab para rasul. Secara khusus, Yesus memberikan dimensi spiritual dalam imaji sebab menjala manusia berarti perutusan untuk mewartakan Kerajaan Allah. Tanpa dimensi spriritual, imaji menjala manusia tidak berarti dan kehilangan maknanya.

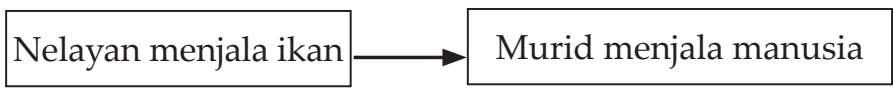

\section{Diagram 2. Analogi Dua Dunia}

Sumber: Hasil Analisis Peneliti

Dengan demikian, kisah panggilan murid perdana mengandung analogi imajinatif. Dengan metode ini, Yesus menghadirkan visi perutusan religius dengan menghadirkan tugas pewartaan rasul dalam perjumpaan perdana-Nya dengan para murid. Pada saat sama, para rasul mengiyakan seluruh visi religius dalam pemahaman analogi imajinatif, yaitu berbagai kemungkinan kisah-kisah di masa depan atas pengalaman perjumpaan di tepi Danau Genesaret tersebut. Dalam perjalanan waktu, pemahaman dan pemaknaan para murid tentunya akan dimurnikan, diperjelas, dan dipertegas. Dalam kisah kebangkitan Kristus, para murid akan mendapat cahaya pemaknaan bagi perutusan visioner religius itu (yang juga terus berkembang sejalan dengan dinamika jemaat perdana). ${ }^{44}$

\section{Analogi Imajinatif dan Pendidikan Karakter}

Pendidikan karakter menyangkut tiga ranah penting dalam pendidikan, yaitu kognitif, afektif, dan psikomotorik. Tetapi, kisah panggilan para rasul mengangkat dimensi ilahi atau religius melalui aspek imajinasi dalam pendidikan. Berikut ini adalah tabel aspek pendidikan yang memasukkan dimensi imajinasi.

$43 \quad$ Ibid., 126.

44 Berbagai pengalaman hidup bersama dengan Yesus, merupakan proses pemurnian yang memperjelas visi religius dalam kisah panggilan murid. Ada yang salah, seperti Yudas yang berkhianat atau Petrus yang menyangkal terhadap Yesus. Ada yang mendobrak pemahaman, seperti Paulus yang membuka cakrawala perutusan yang tidak terbayangkan oleh dua belas rasul, yaitu pewartaan Injil untuk bangsa non-Yahudi. 
YUSUF SISWANTARA

Tabel 3. Aspek Pendidikan Karakter

\begin{tabular}{|c|c|c|c|}
\hline $\begin{array}{c}\text { Aspek } \\
\text { Pendidikan }\end{array}$ & Metode & Dimensi & Hasil \\
\hline Kognitif & Penjelasan & Kesadaran & Pemahaman \\
\hline Afektif & Merasa & Perasaan & Dorongan \\
\hline Psikomotorik & Perintah/Instruksi & Tindakan & Perubahan Perilaku \\
\hline Imajinatif & Imaji & Kreativitas & Visi Masa Depan \\
\hline
\end{tabular}

\section{Sumber: Analisis Peneliti}

Dalam empat aspek tersebut, analogi-imajinatif sekiranya menjadi dasar dari tiga aspek lainnya. Kisah panggilan murid perdana harus diletakkan dalam analogi imajinatif yang berarti pengembangan dimensi spiritual/rohani. Pengaruh dimensi spiritual terlihat jelas dalam kisah para murid setelah penyaliban. Perjalanan Emaus menjelaskan perubahan aspek spiritual dan pengaruhnya kepada seluruh aspek. Perbincangan Yesus sepanjang jalan adalah pengajaran-Nya tentang Kitab Suci dan pemecahan roti merupakan peristiwa yang menghadirkan kembali kisah perjamuan terakhir (bdk. Lukas 24:13-35). Pemecahan roti menyadarkan dua murid tersebut terhadap pengalaman spiritual (Yesus adalah Mesias) dan hal itu mempengaruhi sisi kognitif (ketidaktahuan kepada pencerahan pengetahuan sabda Allah), sisi psikomotorik (perjamuan dan gerak kembali ke Yerusalem), dan sisi afektif (kesedihan menjadi semangat). Singkatnya, hadirnya dimensi spiritual (iman dan keyakinan) akan berpengaruh pada rasa (afektif), pikiran (kognitif), dan tindakan. Untuk lebih jelasnya, posisi aspek analogi-imajinatif digambarkan dalam skema berikut.

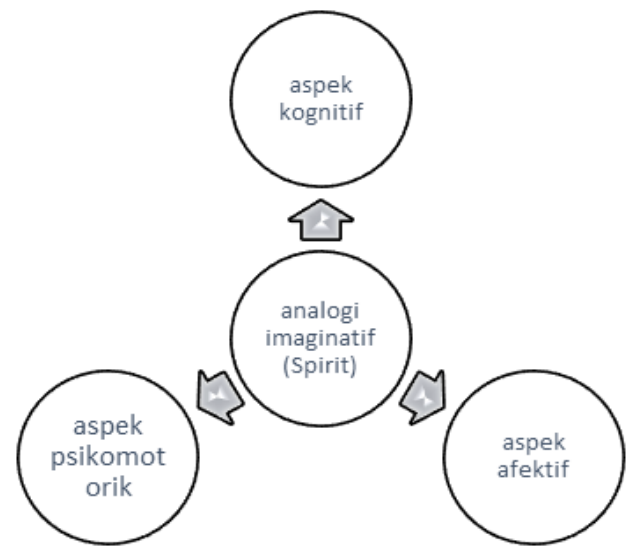

\section{Diagram 3. Analogi Dua Dunia}

Sumber: Analisis Peneliti 
Diagram 3 memperlihatkan bahwa analogi imajinasi (aspek spiritual) akan memberikan kontribusi terhadap tiga aspek pendidikan. Aspek spiritual merupakan domain pendidikan agama Kristen. Pendidikan agama, dengan begitu, dapat mengolah dimensi spiritual peserta didik.

Makna pedagogis atas aspek analogi imajinatif tersebut adalah sebagai berikut. Pertama, analogi imajinatif berarti pendidikan berorientasi pada konteks peserta didik. Orientasi peserta didik ini tentunya tidak asing dalam dunia pendidikan. Tetapi dalam proses pembelajaran, pendidik memperhatikan lingkungan atau konteks peserta didik, baik sosial maupun personal. Lingkungan dan konteks menjadi pintu masuk bagi pemberian pesan (materi pendidikan). Dalam aksiologi, nilai sebagai sebuah pesan disampaikan dengan meletakkannya di konteks peserta didik. Kondisi ini memungkinkan peserta didik dapat menerimanya.

Kedua, analogi imajinatif berarti pengembangan kemampuan reflektif dalam peserta didik. Kemampuan reflektif merupakan suatu keterampilan dalam memberikan makna terhadap setiap peristiwa sehingga peristiwa menjadi kisah di mana subjek turut berperan. Tentunya, ada keberpihakan reflektif tetapi hal itu tidak terhindarkan karena pemaknaan terhadap suatu peristiwa berpangkal dari aku sebagai manusia yang memaknai.

Ketiga, analogi imajinatif berarti kesadaran dua kewarganegaraan dalam diri orang kristiani. Gagasan ini berangkat dari pengajaran Yesus tentang penjala ikan dan penjala manusia. Bagi penjala ikan, menangkap ikan tentunya suatu peristiwa yang biasa dilakukan oleh para murid karena memang itulah profesinya. Sementara itu, penjala manusia merupakan sebuah terminologi untuk menunjuk pada perutusan sebagai kenyataan rohani. Melalui istilah itu, para murid diutus menjadi pewarta Kerajaan Allah. Kiranya, jelaslah bahwa Yesus menyajikan suatu metode yang menggunakan pengalaman nyata untuk menunjukkan pengalaman rohani dalam hal ini perutusan sebagai rasul. Metode analogi imajinatif ini mengorelasikan pengalaman dan kerohanian. Kekhasan metode ini adalah menempatkan dan menyadarkan peserta didik bahwa, sebagaimana diungkapkan Agustinus, setiap orang Kristen mempunyai dua kewarganegaraan: Kerajaan Allah dan Kerajaan Dunia. ${ }^{45}$ Dalam keduanya, orang Kristen mempunyai dua dunia: kemanusiaan dan kerohaniannya. Melalui pendasaran teologis Agustinus, pendidikan agama Kristen mempunyai tugas untuk membangun keterhubungan dua dunia secara utuh dan tak terpisahkan. Artinya, tindakan manusiawi merupakan persembahan yang nyata dan ungkapan pengalaman rohani. Keimanan menerangi dan menjadi kriteria kebenaran

45 Bryan Magee, The Story of Philosophy (London: Dorling Kindersly Limited, 2001), 52. 
dari tindakan manusiawi. Paulus berpendapat bahwa salib bukanlah kebodohan, tetapi karya Allah yang menjadi kekuatan. ${ }^{46}$

Keempat, analogi imajinatif berarti visioner-spiritual. Pendidikan agama Kristen kiranya berorientasi pada masa depan. Peserta didik pun dibawa pada cita-cita masa depan. Hanya saja, cita-cita di sini bukanlah keinginanku untuk ... tetapi keinginan Tuhan atas diriku untuk ... . Pendidikan agama Kristen dapat mengembangkan atau mengasah ketajaman reflektif sehingga siswa mampu membedakan keinginanku dan keinginan Tuhan bagiku seperti tindakan reflektif Jeanne d'Art di akhir hidupnya ${ }^{47}$ Ignatius Loyola menyebutnya dengan Discernment of Spirits (pembedaan roh). ${ }^{48}$ Dengan berlatih pembedaan roh, peserta didik mampu mengidentifikasi gerakan jiwa. ${ }^{49}$ Dengan keterampilan pembedaan roh, siswa dapat merasakan dan menerima kehendak Tuhan atau panggilan Tuhan, dengan mempercayai bahwa, "Banyaklah rancangan di hati manusia, tetapi keputusan Tuhanlah yang terlaksana" (Amsal 19:21).

Kelima, analogi imajinatif membawa siswa pada pengalaman "aha" (aha experience). ${ }^{50}$ Aha experience mengacu pada pengalaman insight atau pencerahan tiba-tiba. ${ }^{51}$ Dengan mengacu kepada analisis kisah panggilan para rasul, analogi imajinatif menjadi alternatif pedagogis dalam penanaman nilai. Dalam proses ini, pendidik memberikan stimulus sedemikian rupa sehingga para murid takjub dan sujud atau merasakan dan tersentuh. Sekali lagi, kisah perjalanan Emaus menunjukkan "aha experience" bagi dua murid. Melalui pemecahan roti, mereka tiba-tiba memahami ajaran dan peristiwa tentang penderitaan dan kebangkitan Yesus dalam kerangka karya keselamatan Allah. Pengalaman "terbukalah mata mereka dan mereka pun mengenal Dia" (Lukas 24: 31) terjadi seketika dan tiba-tiba. Aha experience ini pula mendorong mereka untuk kembali ke Yerusalem. Artinya, pengalaman aha ini memberikan daya dorong internal dalam diri peserta

46 Bdk. 1 Korintus 1: 18, “Sebab pemberitaan tentang salib memang adalah kebodohan bagi mereka yang akan binasa, tetapi bagi kita yang diselamatkan pemberitaan itu adalah kekuatan Allah"

47 Luc Besson, The Messenger: The Story of Joan of Arc (Film), 1999.

48 Ignatian Spirituality, “Discernment of Spirits," Loyola Press, 2020, https://www.ignatianspirituality. com/making-good-decisions/discernment-of-spirits/.

49 Pembedaan roh adalah interpretasi dari apa yang disebut St. Ignatius Loyola sebagai "gerakan jiwa." Gerakan interior ini terdiri dari pikiran, imajinasi, emosi, kecenderungan, keinginan, perasaan, penolakan, dan daya tarik. Penegasan spiritual terhadap roh melibatkan menjadi peka terhadap gerakangerakan ini, merenungkannya, dan memahami dari mana asalnya dan ke mana gerakan itu menuntun kita.

50 Dictionary American Psycological Association Online, "Aha Experience," accessed March 26, 2021, https://dictionary.apa.org/aha-experience.

51 Amory H. Danek and Carola Salvi, "Moment of Truth: Why Aha! Experiences Are Correct," Journal of Creative Behavior 54, no. 2 (2020): 484-86, https://doi.org/10.1002/jocb.380; Wangbing Shen et al., "Feeling the Insight: Uncovering Somatic Markers of the 'Aha' Experience," Applied Psychophysiology Biofeedback 43, no. 1 (2018): 13-21, https://doi.org/10.1007/s10484-017-9381-1. 
didik. Pencerahan batin membuat peserta didik, tidak hanya menerima nilai (pesan) tetapi juga menghidupi nilai tersebut.

Keenam, analogi imajinatif berarti experiential learning. ${ }^{52}$ Artinya, analogi imajinatif menegaskan model experiential learning (pengalaman sebagai metode pendidikan iman). ${ }^{53}$ Dengan menggunakan konsep Brien Remer tentang konsep GURU, ${ }^{54}$ kisah panggilan menggunakan langkahlangkah pendidikan Grounded (menggali pengalaman dengan mengingat, menghadirkan kembali, memisahkan, atau menghubungkan), Understand (memahaminya dalam konteks yang lebih luas dengan abstraksi atau generalisasi untuk kemudian diuji dan direvisi dalam Revise untuk menemukan pendasaran yang lebih kuat), dan Use (tahap bagi pembelajar untuk menggunakan pemahaman baru dalam kondisi nyata). Sementara itu, David Kolb membahas model yang sama dengan pembahasan yang berbeda: pengalaman konkret (melakukan sesuatu), pengamatan reflektif (memikirkan apa yang sudah dilakukan, konseptualisasi abstrak (menambah pengetahuan dari pengamatan atas apa yang dilakukan), dan praktik (mempraktikkan apa yang telah dikonseptualisasikan). ${ }^{55}$

Melalui paparan di atas, analogi imajinatif merupakan langkah atau metode pembelajaran agama yang berorientasi pada konteks, mengembangkan kemampuan reflektif dalam mengangkat pengalaman manusiawi sebagai pengalaman rohani dan iman, mampu membawa pencerahan pengalaman siswa, dan berorientasi pada perutusan seorang kristiani. Dengan demikian, metode ini menggerakkan empat aspek dalam diri pembelajar, yaitu kognitif, afektif, tindakan, dan aspek spiritualitas dan iman kristiani. Makna pedagogisnya adalah bahwa pengalaman (dalam terang) iman yang disertai tindakan iman jauh lebih berdaya guna dari pengetahuan. Jika mengindahkan hal ini, maka implikasi pendidikan agama adalah menghadirkan pengalaman iman dalam kegiatan-kegiatannya.

\section{Kesimpulan}

Berdasarkan analisis narasi atas kisah panggilan para rasul, penelitian ini menemukan beberapa temuan sebagai berikut.

\footnotetext{
52 Yusuf Siswantara, "Sewaka Darma: Pembelajaran Keutamaan Kehidupan dan Implikasi Pedagogisnya," MELINTAS, 2016, https://doi.org/10.26593/mel.v32i1.1925.46-72; Yusuf Siswantara, “KEUTAMAAN Kritik Teks atas Naskah Sewaka Darma," Research Report-Humanities and Social Science Journal UNPAR, 2015, http://download.garuda.ristekdikti.go.id/article.php?article=1408003\&val=3914\&title=KEUTAMAAN. Kritik Teks Atas Naskah Sewaka Darma.

53 Silberman, Handbook of Experiential Learning, 283-302.

54 D.A Kolb, Experiential Learning: Experience as The Source of Learning and Development (New Jersey: Prentice-Hall, Inc, 1984).

55 Stephanie Stokes-Eley, “Using Kolb's Experiential Learning Cycle in Chapter Presentations," Communication Teacher 21, no. 1 (2007): 26-29, https://doi.org/10.1080/17404620701211584.
} 
Pertama, kisah panggilan para murid memuat makna pedagogis. Pendidikan agama Kristen adalah pembinaan iman di mana belajar dari kisah para murid, pengalaman iman menjadi ujung tombak pendidikan. Kedua, penelitian ini melihat bahwa pola pengajaran Yesus selalu bermuara pada pengalaman iman yang menuntut sikap dan tindakan (atau keputusan). Kisah panggilan menjadi prolog atas pola pengajaran ini dalam kisah-kisah Injil lainnya. Ketiga, dinamika pengalaman iman dan tindakan iman menjadi sumbangan penting dalam pendidikan agama Kristen. Dalam terminologi analogi imajinatif, pendidikan agama Kristen hendaknya dapat dikembangkan dengan bertumpu pada penumbuhan iman para murid melalui pengalaman, refleksi, dan tindakan iman.

Implikasi pedagogisnya adalah sebuah kritik bagi pendidikan agama Kristen, yaitu apakah pendidikan agama Kristen sudah menyentuh dimensi pengalaman iman. Artinya, pendidikan agama Kristen bukan menjadi sekadar penghafal ayat (aspek kognitif), tetapi juga pelaksana ayat. Melalui pemahaman ayat Kitab Suci, para murid harus dibawa pada pengalaman hidup bersama Yesus untuk akhirnya bertindak dalam perbuatan nyata, seperti para murid yang setelah mengalami pengalaman iman, mereka meninggalkan segala sesuatu, lalu mengikuti Yesus (Lukas 5: 11). Jika demikian halnya, maka aktivitas murid dan sistem evaluasi pendidikan agama pun harus direvisi. Evaluasi tidak hanya berfokus pada ujian kertas, tetapi harus berani menerapkan ujian tindakan, entah individual ataupun kelompok. ${ }^{56}$

Konsekuensi praktis yang bisa ditarik adalah sebuah harapan bahwa pengalaman iman menjadi fondasi bagi tindakan dan arah bagi hidup para murid dalam menghadapi berbagai tawaran dunia: kenikmatan duniawi, budaya instan dalam korupsi, eksistensi diri tapi destruktif dalam kekerasan, atau kenikmatan seksual tanpa sikap tanggungjawab dan pengabaian sakralitas perkawinan. Pendidikan agama Kristen hendaknya bisa memberikan fondasi iman bagi generasi muda dalam kondisi-kondisi di atas. Penguatan fondasi iman ini jelas mutlak dibutuhkan jika pendidikan mempertimbangkan perkembangan teknologi yang memberikan akses informasi, entah yang bermuatan baik ataupun buruk.

Pengalaman iman dalam perjumpaan personal dengan Yesus melalui pendidikan agama Kristen pun mampu memberikan dasar pijakan pertobatan seturut ajaran iman. Keyakinan ini berdasar dari pengalaman dua rasul: Santo Petrus dan Santo Paulus. Santo Petrus menyangkal Yesus saat penderitaan Yesus dan tindakan ini menunjukkan kelemahan badani dan kemanusiaan (Matius 26:30-35), tetapi tekad Santo Petrus untuk bertobat

56 Ujian tindakan bisa berupa, misalnya, evaluasi berbasis proyek. 
dan mewartakan Yesus Kritus adalah keputusan hebat yang berdasar atas iman kepada Yesus Kristus, meski dalam kejatuhan. Demikian pula, Santo Paulus yang semula penganiaya murid Yesus kemudian berbalik, bertobat, dan menjadi pewarta Injil karena pengalaman iman lewat pertemuannya dengan Yesus Kristus (Kisah Para Rasul 9: 3-9).

Penelitian ini kiranya bisa memberikan rangsangan bagi penelitian lanjutan. Rekomendasi penelitian selanjutnya adalah, misalnya, project base learning dalam pengembangan iman, eksplorasi daya imajinasi dalam pendidikan agama, dan storytelling sebagai media pengembangan iman dalam pendidikan nilai agama Kristen, ataupun pengembangan pendidikan agama melalui pendekatan experiential learning.

\section{Daftar Pustaka}

Alfian Dwi Primantoro. "Pendidikan Nilai Moral Ditinjau dari Perspektif Global." JPK: Jurnal Pancasila dan Kewarganegaraan 1, no. 1 (2016): 1-8.

Alvira, Mirza, Nur Hidayah, dan Chusniah. "Penerapan Model Analogi untuk Melatih Keterampilan Berpikir Kreatif Calon Konselor." Jurnal Pendidikan 4, no. 1 (2016): 758-764.

Dictionary American Psychological Association Online. "Aha Experience." diakses 26 Maret 2021. https://dictionary.apa.org/aha-experience.

Astika, Made, dan Selvianty Sari Bunga. "Hubungan Kompetensi Sosial Guru Kristen terhadap Perkembangan Karakter Siswa: Tantangan Pendidikan Kristen dalam Mencerdaskan Youth Generation." Jurnal Jaffray 14, no. 1 (2016): 63. https://doi.org/10.25278/jj71.v14i1.189.

Boiliu, Ibrahim, Aeron Frior Sihombing, Christina M Samosir, dan Fredy Simanjuntak. "Mengajarkan Pendidikan Karakter Melalui Matius 5: 6-12." KURIOS: Jurnal Teologi dan Pendidikan Agama Kristen 6, no. 1 (2020): 61-71.

Bryan Magee. The Story of Philosophy. London: Dorling Kindersly Limited, 2001.

D.A Kolb. Experiential Learning: Experience as Th e Source of Learning and Development. New Jersey: Prentice-Hall, Inc, 1984.

Danek, Amory H., and Carola Salvi. "Moment of Truth: Why Aha! Experiences Are Correct." Journal of Creative Behavior 54, no. 2 (2020): 484-486. https://doi.org/10.1002/jocb.380.

F. Budi Hardiman. "Seni Memahami Hermeneutik dari Schleiermacher sampai Derrida." Yogyakarta: Kanisius, 2015.

England, M. "Teaching Methods of Jesus." Thesis, (2014).

Fønnebø, L. A Grounded-Theory Study of the Teaching Methods of Jesus : 
An Emergent Instructional Mode. Graduate Research 1, (2011): 32-41. McCoy, J. W. The teaching methods of Jesus. The Journal of Biblical Foundations of Faith and Learning 1, no. 1 (2016): 1-16. https://knowledge.e.southern.edu/jbffl/vol1/iss1/9.

Haryatmoko. "Analogi Permainan Ricoeur dalam Imajinasi Sastra: Imajinasi Melampaui Sangkar Moral." BASIS 13-18 (2005): 1-12.

Kadarmanto, Mulyo. "Mengkaji Revolusi Mental dalam Perspektif Pendidikan Kristen." Polyglot: A Journal of Language, Literature, Culture, and Education 12, no. 1 (2016): 103-118. https://ojs.uph.edu/ index.php/PJI/article/view/388.

Kama Abdul Hakam. Model Pembelajaran Pendidikan Nilai. Bandung: CV. Yasindo Multi Aspek, 2010.

KBBI. “Kamus Besar Bahasa Indonesia." KBBI. 2020. https://kbbi.web.id/ analogi.

Ignatian Spirituallity. "Discernment of Spirits." Loyola Press, 2020. https://www.ignatianspirituality.com/making-good-decisions/ discernment-of-spirits/.

Luc Besson. The Messenger: The Story of Joan of Arc (Film), 1999.

Markes, Karlito D. "Living Values Education dan Implikasinya bagi Pendidikan Agama Kristen." Manna Rafflesia 6, no. 2 (2020): 220-40. https://doi.org/10.38091/man_raf.v6i2.120.

Maslow, Abraham H. Religion, Value, and Peak-Experiences. Columbus: Ohis State University Press, 1964.

Nata, Abuddin. "Peran Pemuda dalam Sektor Pendidikan." UIN Jakarta. 2020. uinjkt.ac.id.

Panuntun, Daniel Fajar, dan Eunike Paramita. "Hubungan Pembelajaran Alkitab terhadap Nilai-Nilai ( Kelompok Tumbuh Bersama Kontekstual )." Gamaliel : Teologi Praktika 1, no. 2 (2019): 104-115.

Presiden Republik Indonesia. “Undang-Undang Republik Indonesia Nomor 12 Tahun 2012 tentang Pendidikan Tinggi." 2012.

Saptorini, Sari. "Pemanggilan Murid Secara Sengaja Berdasarkan Teladan Tuhan Yesus." PASCA : Jurnal Teologi Dan Pendidikan Agama Kristen 15, no. 1 (30 November 2019): 35-43. https://doi.org/10.46494/ psc.v15i1.67.

Setiawan, David Eko. “Kelahiran Baru di Dalam Kristus Sebagai Titik Awal Pendidikan Karakter Unggul." Evangelikal: Jurnal Teologi Injili Dan Pembinaan Warga Jemaat 3, no. 2 (2019): 154. https://doi.org/10.46445/ ejti.v3i2.135.

Shen, Wangbing, Yu Tong, Yuan Yuan, Huijia Zhan, Chang Liu, Jing Luo, and Houde Cai. "Feeling the Insight: Uncovering Somatic Markers 
of the 'Aha' Experience." Applied Psychophysiology Biofeedback 43, no. 1 (2018): 13-21. https://doi.org/10.1007/s10484-017-9381-1.

Sidjabat, Binsen S. "Penguatan Guru PAK untuk Pendidikan Karakter." Evangelikal: Jurnal Teologi Injili Dan Pembinaan Warga Jemaat 3 (2019): 30-48.

Sidjabat, Binsen Samuel. “Kerangka Kurikulum Pendidikan Agama Kristen Berbasis Karakter Di Perguruan Tinggi Character-Based Christian Religious Education Curriculum Framework in Higher Education." Jurnal Jaffray 17, no. 1 (2019): 73-90. https://doi.org/10.25278/ jj.v17i1.314.

Silberman, Bel. Handbook of Experiential Learning. Pfeiffer I. San Francisco: Pfeiffer, 2007.

Siburian, T. "Perspektif Kristologis Mengenai "Yesus Guru Agung"." Jurnal Teologi Stulos 2 (Juli 2018): 179-206. http://sttb.ac.id/download/stulos/ stulos-v16-no02/Stulos-Vol16-No-2-Perspektif Kristologis Mengenai Yesus Guru Agung.pdf.

Siswantara, Yusuf. "Keutamaan Kritik Teks Atas Naskah Sewaka Darma." Research Report-Humanities and Social Science Journal, UNPAR, 2015. http://download.garuda.ristekdikti.go.id/article.php?article=1408003\&val=3914\&title=KEUTAMAAN Kritik Teks Atas Naskah Sewaka Darma.

Siswantara, Yusuf. "Sewaka Darma: Pembelajaran Keutamaan Kehidupan Dan Implikasi Pedagogisnya." MELINTAS, 2016. https://doi. org/10.26593/mel.v32i1.1925.46-72.

Stevens, G. B. "The Teaching of Jesus. II. The Methods of His Teaching." The Biblical World 5, no.2 (1895): 106-113. The University of Chicago Press. https://www.jstor.org/stable/3135144.

Stokes-Eley, Stephanie. “Using Kolb's Experiential Learning Cycle in Chapter Presentations." Communication Teacher 21, no. 1 (2007): 26-29. https://doi.org/10.1080/17404620701211584.

Sunarko, Andreas Sese. "Implikasi Keteladanan Yesus Sebagai Pengajar bagi Pendidikan Kristen yang Efektif di Masa Kini." REGULA FIDEI: Jurnal Pendidikan Agama Kristen 5, (September 2020): 118-131.

Tafonao, Talizaro. 2019. "Penerapan Strategi Pengajaran Tuhan Yesus Terhadap Pencapaian Tujuan Pendidikan Agama Kristen." AgriXiv. July 25. doi:10.31220/osf.io/a4b76.

Tarigan, Musa Sinar. "Implikasi Penebusan Kristus dalam Pendidikan Kristen [the Implication of Christ'S Redemption on Christian Education]." Polyglot: Jurnal Ilmiah 15, no. 2 (2019): 203. https://doi.org/10.19166/ pji.v15i2.1409. 
Telaumbanua, Arozatulo. “Peranan Guru Pendidikan Agama Kristen dalam Membentuk Karakter Siswa." FIDEI: Jurnal Teologi Sistematika Dan Praktika 1, no. 2 (2018): 219-231. https://doi.org/10.34081/fidei.v1i2.9. Hanifah, Umi, Ronggo Alit, and Sugiarto Sugiarto. "Penggunaan Metode Black Box Pada Pengujian Sistem Informasi Surat Keluar Masuk." SCAN - Jurnal Teknologi Informasi Dan Komunikasi 11, no. 2 (2016): 33-40. http://ejournal.upnjatim.ac.id/index.php/scan/article/view/643.

KBBI. “Kamus Besar Bahasa Indonesia." KBBI. 2020. https://kbbi.web.id/ propaganda. 